DOI 10.37882/2223-2982.2020.05.40

\title{
ОСОБЕННОСТИ И ОБСТОЯТЕЛЬСТВА ЗАКЛЮЧЕНИЯ ИМПЕРАТОРОМ ФЕОДОСИЕМ ДОГОВОРА С ГОТАМИ В 382 ГОДУ
}

\section{FEATURES AND CIRCUMSTANCES OF MAKING TREATY BY EMPEROR THEODOSIUS WITH THE GOTHS IN 382 \\ S. Yartsev M. Ryabtseva}

Summary: The article is devoted to a complex topic of the features and circumstances of the making the treaty by emperor Theodosius with the Goths in 382. For the first time in historiography, the authors consider this issue in the context of the complicated internal political confrontation in the country and taking into account differences of barbarian groups making "foedus» agreement with the Empire. According to the authors, if some barbarians wished to become allies and soldiers of Western Rome, though the opposing part fundamentally sought a contractual relationship with the other - the eastern part of the Empire. For this reason, both groups of barbarians could summon the Roman authorities to the unprecedented conditions for staying in the territory of Rome. However, the attempt of the Romans to solve by treaty such acute problems as the Gothic threat, the lack of new recruits for the army and the lack of an agricultural population on devastated lands, showed their failure very soon.

Keywords: Roman Empire, Emperor Theodosius I, Emperor Gratianus, Goths, Huns, federates.
3 аключение договора императора Феодосия с готами 382 года, как ключевое событие римской позднеантичной истории, имеет достаточно обширную историографическую базу [7, с. 191-192; 8, с. 418; 10, с. $232-243 ; 14$, c. $95 ; 18$, c. $43 ; 23$, p. $149-181 ; 24$, p. $182-189$; 27, р. 363-364; 28, р. 191; 29, р. 51]. Однако, из-за фрагментарности и тенденциозности источников, очень многие вопросы, связанные с этой переломной вехой в истории, до сих пор не ясны. Тем не менее, не вызывает сомнений, что к заключению такого договора, привела целая цепь событий, последовавшая после разгрома римской армии варварами в битве при Адрианополе в 378 году и гибели в ней императора Валента.

Указанная катастрофа превратила Грациана в единоличного правителя всей империи. Его младший брат был еще мал, чтобы править самостоятельно и всю полноту власти молодой император сконцентрировал в своих руках [8, с. 416-417]. При этом, ситуация в империи требовала незамедлительных решений, так как «варвары

\section{Ярцев Сергей Владимирович}

Д.и.н., дочент, Тульский государственный педагогический университет им Л.Н. Толстого

s-yartsev@yandex.ru

Рябцева Марина Леонидовна

К.и.н., Белгородский государственный начиональный исследовательский университет ryabtseva@bsu.edu.ru

Аннотация: Статья посвящена сложной теме особенностям и обстоятельствам заключения императором Феодосием договора с готами в 382 году. Впервые в историографии авторы рассматривают данную проблему в контексте сложного внутриполитического противостояния в государстве и с учетом различий варварских групп заключавших «foedus» с империей. По мнению авторов, если одни варвары, сами желали стать союзниками и солдатами западного Рима, то противостоящая им сторона, принципиально искала договорных отношений с другой, восточной частью империи. По этой причине обе группы варваров, смогли вытребовать у римских властей беспрецедентные условия пребывания на территории Рима. Однако стремление римлян, решить посредством договора, такие острые проблемы, как готскую угрозу, нехватку новых рекрутов для армии и недостаток земледельческого населения на разоренных землях, очень скоро показало свою несостоятельность.

Ключевые слова: Римская империя, император Феодосий I, император Грациан, готы, гунны, федераты.

захватили Фракию, постоянно разоряли Мёзию и Паннонию» (Zosim., IV, 24, 4). Более того, вести о победе варваров над римлянами распространялись все далее, провоцируя племенной мир на выступления против империи (Zosim., IV, 24, 4). Такие нападения, определенно создавали угрозу удара в тыл, решившему выдвинуться на Восток Грациану. Еще одна опасность исходила уже из Иллирика, особенно из Паннонии, Реции, Норика, то есть из всех тех мест, через которые можно было добраться до Рима. Значимость этих территорий возросла из-за превращения Апеннинского полуострова после Адрианополя в приграничную провинцию и теперь именно от обороны альпийских горных перевалов, зависела безопасность Италии [18, с. 141-143]. В этой связи Грациан, вынужден был, в первую очередь, беспокоиться о защите Паннонии, не давая готам ни одного шанса прорваться в западные провинции империи.

Существует мнение, что еще до битвы при Адрианополе из Испании был вызван находившийся в опале Фе- 
одосий - сын казненного в 375 году старшего Феодосия - победителя варваров в Британии и Африки. Этот относительно еще молодой человек, приходился Грациану кузеном (мужем его сестры) (Malal., XIII, 37). Подозревают, что у попавшего в немилость сына после казни отца, при дворе императора оставались сильные сторонники, которые и помогли Феодосию с новым назначением [8, с. 417], тем более что этому способствовало его приверженство никейскому христианству [3, с. 438]. Если это так, то Феодосий-младший действительно мог возглавить римские войска в Иллирике и после победы варваров в битве при Адрианополе не дать им пройти через эту провинцию в Италию (Theod., V, 5-6). В пользу такого развертывания событий, свидетельствует небольшой промежуток времени между битвой при Адрианополе и провозглашением императором Феодосия, который в момент гибели Валента, должен был находиться, где-то недалеко [18, с. 42].

Как бы то ни было, идея о новом августе Востока, вызрела у римской элиты не сразу. Видимо, только после многодневной обороны Паннонии укрепившимся здесь Грацианом (Auson. Grat. Actio, 9, 42), к нему пришло осознание всей тяжести сложившейся ситуации в государстве. По этой причине, Грациан был вынужден провозгласить своим соправителем, скорее всего, уже достойно отличившегося перед этим, magister militum Феодосия. 19 января 379 года Феодосий стал августом восточных провинций и получил под свое управление сильно пострадавшие и захваченные варварами диоцезы Фракии и Македонии (Socrat., V, 2; Phil., 9,17; Chron. Pasch., 561, 1-4; Pac., 9-11; Them. Or., 14, Epit., 47,3; Theod., V, 5,1 - Vl, 3). С целью усилить ресурсы нового августа, Грациан решает «Иллирию и на востоке подвластные области», также «поручить Феодосию» (Soz., VII, 4). Провинция Иллирик, как известно широко славилась своими отменными рекрутами, конями [18, с. 131, 143], а также продуктами сельскохозяйственного производства (оливковым маслом, хлебом, сыром, рыбой, солониной и т.д.) [1, с. 284-285]. Возможно, таким решением, окружение Грациана хотело подчеркнуть, что теперь Феодосий исключительно с опорой на собственные силы, должен был восстановить восточную армию, прогнать варваров и навести порядок в подчиненных ему провинциях. Однако, в будущем такая передача стратегической для Италии территории, безусловно, создавала проблемы в отношениях между западной и восточной частями империи [25, р. $28 ; 22$, р. $195 ; 18$, с. 126]. Дело в том, что на востоке область Иллирика не пользовалась той значимостью, которой эта провинция обладала на западе. При опасности нападения на Востоке, здесь думали об Иллирике только в последнюю очередь. Это оставляло Италию один на один с неприятелем, который, перейдя Дунай, в дальнейшем через территорию Иллирика, легко мог вторгнуться на Апеннинский полуостров [18, с. 126].
Анализ источников свидетельствует, что новый император рассчитывал на помощь Грациана и был искренне убежден в скорой полной победе над готами. Действительно, уже весной 379 года, началась совместная победоносная военная кампания двух императоров против варваров на Балканах, (Socrat., V, 6) и на территории Фракии (Jord. Get., 140). Стало складываться впечатление, что окончательный разгром противников и изгнание их с территории империи, является делом самого ближайшего времени. Во всяком случае, Феодосий в своей победоносной речи на заседании сената в Константинополе 17 ноября 379 года, заявил о полной победе над врагами, в число которых он включил и гуннов (Cons. Const., а. 379). При этом все это происходило, уже после того, как Грациан, получив информацию о прорыве аламанами западной границы, срочно покинул восточные провинции (Socr., V, 6). Тем не менее, победоносным настроением были охвачены многие слои римского общества, требовавшие гнать варваров назад (Them. Or., XIV, 181 b, c), и восхвалявшие успех молодого Грациана, буквально за один год, отомстившему готам за позорное поражение своего дяди (Auson. Grat. Actio, II, 7-8).

Однако уход западной армии, оставил Феодосия один на один с недобитыми врагами. Возможно, Грациан полагал, что скорое восстановление армии с опорой на ресурсы богатых провинций и эффективное государственное управление, предпринятое Феодосием, доведут начатое дело до логического победоносного конца. Феодосий, действительно начал активные действия в указанных направлениях, которые, однако, привели к неоднозначным результатам. Так, решение о необходимости военной реформы, и первые действия в этом направлении, император вполне мог предпринять, именно в это неспокойное для него время [12, с. 179, прим. 1]. Однако, пытаясь при этом найти рекрутов для своей новой армии, император, стал призывать в нее не только земледельцев или рабочих рудников (Lib. Or., XXIV, 15; Them. Or., XIV, 181 b, c), но и варваров. В последнем случае, конечно, не было никакой дискриминации «но не велось и никакого учета» (Zosim., IV, 31, 1). При этом, начав варваризацию армии, Феодосий слишком поздно обратил внимание на то, что многие варвары «согласились присоединиться к римским солдатам, прежде всего, руководствуясь мыслью о том, что как только увеличится их количество, тем легче им будет атаковать и добиться полного контроля над ситуацией» (Zosim., IV, $30,1)$. Все это привело к довольно печальным событиям, завершившимся разгромом новой римской армии в 380 году и бегством самого Феодосия, чуть было не попавшего в плен к варварам (Zosim., IV, 30-31).

Действительно, из-за низкого уровня боевых качеств и недостаточной преданности новых солдат [2, с. 243], говорить о военном потенциале вновь набранных подразделений, не приходилось. Все это и привело к ката- 
строфической ситуации, в которую попал Феодосий, пытаясь отразить новое вторжение варваров в 380 году. Очевидно также, что разгром «восточной» армии Феодосия (Zosim., IV, 31), явился закатом римской политики решительных генеральных сражений. Необходима была срочная смена тактики по отношению к варварам, которая, по сути, теперь решала все.

Таким образом, у Феодосия не вышло создать новую римскую армию и остановить готов, а ведь это было главное, что должен был он сделать, после провозглашения его императором. Более того, своим разгромом, он фактически поставил под угрозу Италию, так как, праздновавшие победу варвары, теперь могли легко прорваться через слабо охраняемые перевалы на Апеннинский полуостров. К тому же, большую часть воинских подразделений Паннонии, Феодосий перевел в создаваемую им армию для борьбы с готами, ослабив оборону важной для запада местности [15, с. 24]. Видимо не слишком преувеличивал Зосим, когда сообщал, что при Феодосии «армия значительно ослабла и фактически прекратила свое существование» (Zosim., IV, 29, 1). Поэтому, в то время, когда варвары безнаказанно грабили Балканы, ему ничего не оставалось делать, кроме, как вновь просить Грациана, «как можно быстрее прислать помощь» (Zosim., IV, 32, 1). Обычно считается, что Грациан, в этот раз ограничился отправкой на восток корпусом под командованием Баутона и Арбогаста - франков на римской службе (Zosim., IV, 33, 1). Сам же он остался дома, по той причине, что больше не хотел подвергать западные провинции риску нападения в свое отсутствие [2, с. 213]. Однако посланная западная армия лишь вытеснила занимавшихся грабежом варваров из Македонии и Фессалии во Фракию (Zosim., IV, 33, 2), явно выполняя свою основную задачу, обезопасить подходы к путям, ведущим на запад. Грабежи населения восточной части империи продолжались, и неспособность Феодосия положить этому конец, по-видимому, сильно стала раздражать высшее римское руководство Запада. Не исключено, что именно неудачи Феодосия в военном деле, фактически предопределили его дальнейшую судьбу.

Считается, что в начале сентября 380 года Феодосий встречался с Грацианом в городе Сирмии на территории Паннонии II [27, р. 212, n. 78], после чего, по неизвестной причине, сразу же тяжело заболел безнадежным недугом (Socr., V, 6; lord., Get., 141). Правда по тексту Сократа (Socr., V, 6) выходит, что император заболел еще в 379 году после совместного похода с Грацианом, а выздоровел только в ноябре 380 года, что, похоже, является ошибкой вследствие объединения в тесте событий двух кампаний [2, с. 575, прим. 739]. В любом случае, на Западе данная новость могла быть воспринята, как сигнал скорой смены власти на Востоке. Это следует из дальнейших предпринятых шагов Грациана, в достаточной степени логичных, особенно, если сравнить их с его недавними действиями после битвы при Адрианополе. Заметим, что в обоих случаях, его, в первую очередь, беспокоила защита путей ведущих на запад. Видимо пытаясь их прикрыть, он отправляет комита военных дел «Виталиана в качестве магистра в Иллирик» (Zosim., IV, 34, 1). При этом Грациан полностью игнорирует тот факт, что, еще недавно, провинция была переподчинена Феодосию. Что же касается последнего, то где-то, незадолго до 24 ноября 380 года, дня, когда император вступил с триумфом в Константинополь (Zosim., IV, 33, 1; Soc., 5,6; Cons. Const., s.a. 380,2), еще находясь в Фессалониках, он принимает святое крещение от епископа Ахолия (Socr., V,6; Soz.,VII, 4). То, что в те времена, данное таинство нередко совершалось только перед смертью [6, с. 252-253], свидетельствует о крайне тяжелой ситуации со здоровьем императора, которому явно, в этот момент, было не до пограничных провинций.

К сожалению, последующие события, известные в основном по рассказам Зосима и Иордана, столь противоречивы и запутаны, что на них следует остановиться подробнее, так как, безусловно, они являются ключевыми для понимания дальнейших взаимоотношений римлян с варварами. Судя по тексту Иордана, то, что «император Феодосий заболел, и состояние его было почти безнадежно», придало «готам дерзости» и стало причиной разделения их войска на две группировки. Одна, во главе, с Фритигерном отправилась «грабить Фессалию, Эпиры и Ахайю, Алатей же и Сафрак с остальными полчищами устремились в Паннонию. Когда император Грациан, - который в то время по причине нашествия вандалов отошел из Рима в Галлию, - узнал, что в связи с роковым и безнадежным недугом Феодосия готы усилили свою свирепость, то немедленно, собрав войско, явился туда» (lord. Get., 141).

Действительно, участие в военной кампании 380 года двух сильных варварских армий против римлян, не вызывает сомнений, так как подтверждается сообщением Зосима (Zosim., IV, 34, 2). Однако римский историк ничего не говорит о предшествующем разделе единых готских сил на две группировки, которые, судя по всему, изначально действовали независимо друг от друга. Более того, Фритигерн не мог безнаказанно вторгнуться осенью 380 года в Грецию, так как, буквально, перед этим, все варвары были вытеснены оттуда во Фракию западной армией. Создается впечатление, что поход Фритигерна на Грецию из Гетики Иордана и война многочисленной армии Баутона и Арбогаста с варварами в Греции, известная из Истории Зосима, это рассказ об одних и тех же событиях. Если это так, то они не имеют никакого отношения к болезни Феодосия, так как начались, за несколько месяцев до ее начала. Конечно, мы не можем исключить того, что после получения сведений о тяжелом состоянии императора, варвары все же вновь попытались прорваться в Фессалию и дальше вглубь 
материковой Греции, однако здесь в это время уже действовала римская армия, подошедшая с Запада. В любом случае, она быстро бы пресекла эти попытки.

Следовательно, только поход группировки Алафея и Сафрака, мог иметь хронологическое соответствие с рассказом о нападении варваров на восточные провинции после известий о тяжелой болезни Феодосия. В этой связи, обратим внимание, что война с вандалами, которая по Иордану задержала Грациана в Галлии, на самом деле, неизвестна по другим источникам. Ближайшее нападение указанных варваров датируется здесь 405/6 г. $[13$, с. 287, прим. 420; 16, с. 71]. Тем не менее, Зосим действительно подтверждает наличие в это время тяжелой ситуации в Галлии, только связывает ее не с вандалами, а все с теми же, двумя армиями германцев, базировавшимися, по его словам, за Рейном. При этом в отличие от Иордана, который сообщает о походе на восток самого Грациана, у Зосима мы видим, прямо противоположную картину. После того, как варвары «создали такую угрозу Галлии, что император Грациан был вынужден позволить им оставить Галлию, пересечь Данубий и занять Паннонию и Верхнюю Мёзию. Этим он надеялся освободиться от их беспрерывных нападений» (Zosim., IV, 34, 2). Другими словами, уже на западе с некоторыми из данных варваров мог быть заключен федеративный договор на их расселение на землях в провинции Паннонии, которую теперь они, безусловно обязаны были защищать от других племен.

Тем не менее, заметим, что заключение такого союза, со всеми окружающими империю варварами, не имело никакого смысла, так как полностью разрушало римское государство. Тем более что на обеспечение повышенных потребностей стольких людей, не хватило бы ресурсов всей империи. Противоречит логике стратегии и заключение одновременного союза сразу с двумя упомянутыми группировками - армиями варваров. Они имели разное происхождение и отличались по своей внешнеполитической ориентации по отношению к Римской империи. В этой связи римлянам целесообразнее было противопоставить их друг другу, чем сплотить единым союзом с империей. Алафей и Сафрак, напомним, были опекунами малолетнего «царя гревтунгов» Видериха (правнука Гуннимунда) (Amm. Marc., XXXI, 3, 12) [19, с. 269-272], Фритигерн, же имел непосредственное отношение к тервингам, изначально являясь, скорее всего, опекуном другого малолетнего рикса [19, с. 251-252]. Первую группировку можно назвать проримской. Дед Видериха - Торисмуд являлся братом Гезимунда, верного союзника гуннов (lord., Get., 81, 248) и римлян [19, с. 253-255]. Эти варвары изначально были настроены на взаимовыгодное сотрудничество с империей и участие их в битве при Адрианополе, произошло исключительно благодаря ошибочной политике Валента. Еще одной из характерных их особенностей, было то, что они были эт- нически достаточно разнородны [4, с. 165; 7, с. 189-191], и поэтому современники нередко применяли к ним такие эпитеты, как «готская конница», «отряд аланов» или «храбрые гунны» (Amm. Marc., XXXI, 12, 16, 17). Однако, не вызывало сомнений, что именно эти варвары являлись силой, которая могла остановить готов, грабивших сейчас территорию Римской империи. Видимо это и явилось главным аргументом для окружения Грациана, решившего вернуть империи ее бывших союзников.

Непосредственным поводом для начала переговоров с варварами, видимо стало то, что посланный в Иллирик Виталиан оказался «недостаточно способный справиться с бедственным положением в армии» (Zosim., IV, 34, 1). Грациану необходимо было вновь отправлять помощь на Восток, иначе враги могли прорваться уже в Италию. Следовательно, пойти на соглашение с Алафеем и Сафраком императора вынудило осознание невозможности военной победы над варварами в связи с катастрофическим состоянием дел на Востоке, разгромом армии и смертельным заболеванием Феодосия [27, с. 244]. Тем не менее, договор с варварами 380 года был выгоден и самому Грациану, так как разъединял врагов, противопоставлял друг другу наиболее мощные их группировки. Более того, важным результатом этого соглашения, явилось окончательное отчуждение de facto у Феодосия территории ряда провинций, начатое еще с отправки сюда Виталиана [21, s. 602]. Судя по всему, варвары должны были занять земли, прикрывающие проходы к западным провинциям империи и имеющие стратегическое значение для Италии. По мнению Х. Вольфрама, варвары расселялись в Паннонии II, а также в Савии и Валерии [7, с. 190]. Таким образом, Грациан «добился с ними мира и заключил союз, полагаясь не на оружие, но намереваясь победить их милостью и дарами и предоставить им продовольствие» (lord. Get., 141).

К сожалению, конкретные пункты договора 380 года, нам неизвестны. Мало, что нам может прояснить и ближайший к нашему времени эдикт Гонория 406 года, кроме того, что федераты несли воинскую службу и могли иметь рабов (CTh., VII, 13,16). Использовали же федератов, в основном в качестве вспомогательных войск [11, с. 37-39]. Однако несмотря на то, что статус этих людей расселенных в Паннонии остается неясным, они безусловно должны были отличаться от обычных военнопленных - летов, которых вынужденно расселяли на пустующих землях для обеспечения снабжением продовольствия городов и армии [5, с. 26]. Несколько подробнее о федератах рассказывает Прокопий Кесарийский, отмечая, что «в прежние времена к федератам причислялись только те из варваров, которые не находились в подчинении у римлян, поскольку не были ими побеждены, но пришли к ним, чтобы жить в государстве на равных с римлянами правах. Словом «foedera» римляне называли договор о мире, заключенный с врагами» (Proc. Bell., III, 11, 3-4). 
При этом договор, который обычно заключали римляне с варварами, всегда являлся личным, с человеком, а не с государством. По случаю смерти такого человека, договор расторгался и в дальнейшем требовал возобновления, нередко на иных условиях [11, с. 36]. Другими словами, расселенные на территории Паннонии варвары, были ответственны за его исполнение только перед Грацианом. Вряд ли можно согласиться с мнением, что решение о расселении варваров в Паннонии было принято совместно двумя императорами, например, на совещании в Сирмии [27, р. 222-223]. Этому противоречат вполне определенные свидетельства о заключении договора, именно без участия Феодосия: «Когда в дальнейшем император Феодосий выздоровел и узнал, что император Грациан установил союз между готами и римлянами, - чего он и сам желал, - он воспринял это с радостью и со своей стороны согласился на этот мир» (lord., Get., 142).

На самом деле, пошедший на поправку Феодосий, после заключенного Грацианом договора с варварами, столкнулся с более серьезной проблемой, чем просто с потерей управления отдельными провинциями. Фактически его западным соправителем на приграничной территории, были расселены варвары с узаконенными привилегиями, которые, в любой момент могли быть использованы лично против него и восточной части Римской империи в целом. Не случайно, видимо Зосим сохранил какие-то глухие свидетельства об относительно опасном географическом расположении Паннонии, в том числе и для восточных провинций, ведь варвары легко могли пересечь «Данубий с намерением пройти через территорию Паннонии к Эпиру и оттуда атаковать греческие города» (Zosim., IV, 34, 3). Хотя, конечно, основная цель этого пассажа, более напоминает попытку автора согласовать в одном тексте разные сведения о действиях двух варварских армий.

Отметим также, что заключение договора с одними варварами, безусловно, становилось сигналом к войне с римлянами, для других. При этом у готов, теперь появлялось право требовать, по меньшей мере, тех же привилегий, которые получили расселившиеся в Паннонии варвары. Тервинги почитали свой королевский род не менее знатным, чем Амалы (lord., Get., 42) и имели все основания, принять от римлян тот же комплекс прав и обязанностей, которым воспользовались их соседи. Правда, слишком серьезные уступки вчерашним врагам, создавали угрозу существованию самого государства и не могли устраивать самого Феодосия. Тем не менее, император был вынужден искать компромисс с готами, так как только они могли создать силовой противовес варварам Алафея и Сафрака, за которыми определенно стояли как грейтунги, так и набирающие силу гунны. Учитывая сложные взаимоотношения с Грацианом, при котором, в свое время, казнили его отца, договор с готами для Феодосия, теперь превращался в вопрос выживания восточной части империи и его лично.

Было очевидно, что ухудшающиеся отношения между императорами, легко могли привести к обострению ситуации в государстве, и поставить последнюю точку в карьере и судьбе самого Феодосия. Видимо, совсем не случайно, после 380 года, ему будет полностью свернута помощь Грацианом, который, впрочем, вплоть до своей гибели, совсем отдалится от военных дел, переподчинив командование Баутону, Арбогасту, Меробавду [2, с. 214]. Любопытно, но и Феодосий после своего выздоровления резко изменит свое отношение к Грациану, перестав просить западную помощь и устремив все свои силы на укрепление восточной части государства.

Безусловно, что такие повороты в политике Феодосия могли произойти только в случае его твердой уверенности в невозможности оказания ему западной помощи в новых условиях. Так как все эти трансформации начинают прослеживаться сразу же после выздоровления императора, напрашивается мысль о возможной причастности Грациана или его ближайшего окружения к причине болезни Феодосия (отравления?) и соответствующих подозрениях, на этот счет, последнего. Конечно, такой вариант произошедших событий недоказуем, однако, противоречия между Западом и Востоком, включая даже религиозные дела, стали стремительно нарастать именно после болезни императора.

Таким образом, главной задачей, которая наиболее остро стояла перед императором Востока, была нормализацией отношений с готами. Так как события в империи вынуждали сделать это по возможности быстро, для того, чтобы заставить варваров пойти на уступки, Феодосию необходимо было существенным образом изменить тактику давления на них. С этой целью для пресечения грабежей, римляне стали больше использовать нападения на небольшие отряды варваров, используя опыт подобных действий, полученный еще в самом начале правления Феодосия [8, с. 419-420]. По мнению исследователей, такие серьезные изменения в воинских тактических приемах в отличие от принципов ранней империи, были связаны, в первую очередь, с нехваткой людских ресурсов [18, с. 219]. Тактика описанная Вегецием (Veg. Epit. Rei Mil., 3,9) и позднее Маврикием, действительно подразумевала при превосходящих силах противника, «утомить врага уловками, внезапными набегами ... и никогда не ввязываться в генеральное сражение, исход которого зависит скорее от удачи, чем от храбрости» (Maur. Strat., VIII, 2, 4). При этом, заметим, что и сами готы, понимая, что их обеспечение продовольствием завесило от благосостояния населения, старались теперь по возможности, не опустошать сельскую местность, а под угрозой нападения, периодически получать снабжение у жителей городов. В ответ Феодосий, просто дожидался 
ухода готов с конкретной территории, а затем размещал за городскими стенами свои гарнизоны. При возвращении варваров, горожане уже отказывались снабжать их всем необходимым, а регулярные войска удерживали готов от нападения. Расчет был на то, что голод заставит варваров подчиниться императору [18, с. 42-43]

Крайняя заинтересованность Феодосия в мире с готами и желание заполучить их воинов в ряды своей армии, хорошо видна из его отношения к Атанариху, который из-за интриг в варварской среде, в начале 381 года был выдворен из своего «царства и поехал к Феодосию, который только что начал выздоравливать от болезни, угрожавшей его жизни» (Zosim., IV, 34, 4-5). После последующей скорой смерти готского вождя, император похоронил его в «царской усыпальнице», роскошь которой была такова, что «вся варварская свита была поражена ее чрезмерностью» (Zosim., IV, 34, 4-5). По-видимому, роль Атанариха, в событиях, предшествующих заключению договора 382 года, нельзя недооценивать. Во всяком случае, Марцеллин Комит, упоминая в своей хронике прибывшего и умершего от болезни в январе 381 года в Константинополь Атанариха, утверждает, что изначально «Феодосий заключил договор» именно с ним (Marcell. Chron., 381).

Как бы то ни было, договор 382 года, когда «в октябре месяце, из-за смерти своего короля Атанариха, все племя готов покорилось римлянам» (Marcell. Chron., 382; Cons. Const. s.a., 382), несмотря на то, что условия его заключения остались неизвестными, безусловно, является эпохальным для истории поздней Римской империи. Прецедентом для его заключения, разумеется, стал союз Грациана с варварами 380 года. Х.Вольфрам вообще считает оба договора единым целым [7, с. 191]. Учитывая единообразие предложенных условий разным группам варваров, с этим можно согласиться.

Что же можно сказать об условиях нового союза? Очевидно, что готы за обязательную службу в армии и ежегодное содержание, получали земли для расселения во Фракии, Мёзии II, и возможно на северо-востоке Прибрежной Дакии. Состояли они в списках специального ведомства и имели над собой начальника комита федератов, а также должностных лиц «оptio», отвечавших за выдачу им жалования. При этом они сохраняли в местах своего нового проживания, власть своих вождей и законов. Другими словами, впервые империя жертвовала своей территорией, предоставляя на ней варварам свободную от налогообложения и римского права, широкую автономию. Из ограничений, которых все же удалось отстоять римлянам, можно отметить отсутствие прав собственности варваров на переданную им землю и запрет на браки с римлянами [7, с. 191-192; 8, с. 418; 17, с. $19-20 ; 18$, с. $43 ; 23$, р. $149-181 ; 24$, p. 182-189].
Непосредственно для решения готской проблемы, этот договор, вряд ли, что-то мог изменить в лучшую сторону в исторической перспективе, ведь, несмотря на официальный оптимизм [20, р. 219] контроль над ситуацией в государстве, вскоре вновь будет утерян [26, р. 153-165]. Тем не менее, в данный момент у Феодосия появилась довольно мощная армия, соединившая в единую силу римский и варварский потенциал. Было очевидно, что императору удалось мобилизовать все имеющие ресурсы, для укрепления государства и своей личной власти, и по этой причине с уверенностью смотреть в завтрашний день. Теперь ему было чем ответить в случае заговоров, военных конфликтов и нападений, даже со стороны варварских федератов Грациана. Конечно, Феодосию для содержания своей армии, приходилось увеличивать налоги всеми возможными способами [9, с. 307], но ликвидация внешней и внутренней угрозы, безусловно, того стоила.

Однако не все здесь выглядит, так однозначно. Дело в том, что договор 382 года, уже изначально закладывал серьезные основания для будущих конфликтов с готами, а также между восточной частью империи Феодосия и гуннами. В первом случае, причиной этого служило несправедливое распределение провинций между федератами. Варварам Алафея, Сафрака и союзным им гуннам достались богатые территории, почти не пострадавшие в предыдущих событиях, готам Атанариха и Фритигерна, земли, практически полностью опустошенные ими самими же. Учитывая, что федераты фактически кормились с выделенных ими территорий, очевидно, что на этой почве конфликт был обеспечен. Что же касается гуннов, то сложная ситуация с ними стала складываться уже тогда, когда Грациан сделал ставку на этих кочевников, расселив их группу, вместе с готами Алафея и Сафрака, в Паннонии. Казалось бы, здесь нет повода для беспокойства, ведь гунны, скорее всего, изначально являлись союзниками империи [19, с. 217-244]. Однако Феодосию, в данной ситуации, ничего не оставалось делать, как срочно заключать союз с готами, враждовавшими с гуннами. При этом заключая договор с вассалами гуннов, фактически ушедшими из под их контроля на территорию империи, Феодосий подрывал экономическую базу кочевников, что не могло в будущем не вызвать с ними серьезный конфликт.

Таким образом, договор 382 года с готами, открывший новую эпоху взаимоотношений с варварами, вместе со своим прецедентом - союзом 380 года, являлись следствием сложной внутриполитической ситуации в империи. Противостояние Рима и Константинополя, хотя отчасти еще скрытое, привело к тому, что западный и восточный императоры все активнее стали переходить к тактике использования варваров в своей борьбе. Любопытно, но и варвары в процессе отношений с римлянами, разделялись на противоборствующие стороны, 
в зависимости от своих политических устремлений. Если одна группа из них, сама желала стать союзниками и солдатами западного Рима, то противостоящая им сторона, принципиально искала договорных отношений с другой, восточной частью империи. По этой причине обе группы варваров, смогли вытребовать у римских властей беспрецедентные условия пребывания на территории Рима. Фактически внутри империи возникли неподконтрольные законной власти и налогообложению, этнические анклавы, создающие непомерную угро- зу территориальной целостности государству. Однако стремление римлян, решить посредством договора, такие острые проблемы, как готскую угрозу, нехватку новых рекрутов для армии и недостаток земледельческого населения на разоренных землях, очень скоро показало свою несостоятельность. Предстоящей потере контроля над ситуацией, во многом способствовали начавшиеся конфликты с федератами, а в последствие и с гуннами, причины которых кроятся в особенностях заключенных союзов с варварами.

\section{ЛИТЕРАТУРА}

1. Анонимный географический трактат «Полное описание вселенной и народов» / Перевод и примечания С.В. Поляковой, И.В. Феленковской // Византийский Временник. - 1956. - Т.8. - С. 277-305.

2. Банников А.В., Морозов М.А. Византийская армия (IV-XII вв.). - СПб.: Евразия, 2017. - 688 c.

3. Буасье Г. Падение язычества. Исследование последней религиозной борьбы на Западе в четвертом веке. - М.: Типография Э.Лисснера и Ю.Романа, 1892. -584 c.

4. Буданова В.П. Готы в эпоху Великого переселения народов. - СПб.: Алетейя, 2001. - 320 с.

5. Буданова В.П. «Чужое» как спасение, «Своё» как тупик // Цивилизация и варварство: механизмы, инструменты и субъекты взаимодействия. - М.: Аквилон, 2014. - Вып. III. - С. 12-40.

6. Величко А.М. История Византийских императоров. От Константина Великого до Анастасия І. - М.: Вече, 2012. - 592 с.

7. Вольфрам Х. Готы. - СПб.: Ювента, 2003. - 656 с.

8. Голдсуорти А. Падение Запада. Медленная смерть Римской империи. -М.: АСТ, 2014. - 733 с.

9. Грант М. Римские императоры: Биографический справочник правителей Римской империи 31 г. до н. э. - 476 г. н. э. - М.: ТЕРРА; Книжный клуб, 1998. $400 \mathrm{c}$.

10. Дельбрюк Г. История военного искусства в рамках политической истории. Т. 2. - СПб.: Ювента, 1994. - 352 с.

11. Ермолова И.Е. Римская империя и федераты в IV в. // Новый исторический вестник. - 2001. - №2(4). - С. 33-44.

12. Зосим. Новая история / Перевод, комментарии, указатели Н.Н. Болгова. - Белгород: Изд-во БелГУ, 2010. - 344 с.

13. Иордан. 0 происхождении и деяниях гетов (Getica) / Пер., вступ. ст., коммент. Е.Ч. Скржинской. - СПб.: Алетейя, 2013. - 512 с.

14. Корсунский А.Р. Вестготы и Римская империя в конце IV - начале V века // Вестник МГУ. Сер. ІХ. История. - М.: Изд-во МГУ, 1965. - №3. - С. 87-95.

15. Мехамадиев Е.А. Проблема разделения армии между Западной и Восточной Римской империей в период регентства Стилихона (395-408 гг.): союзные этнические подразделения и федераты // Античная древность и средние века. - Екатеринбург: Изд-во Урал. ун-та, 2011. - Вып. 40: К 50-летию Уральской школы византиноведения. - С. 21-30.

16. Мюссе Л. Варварские нашествия на Европу: германский натиск. - СПб.: Евразия, 2006. - 399 с.

17. Рябцева М.Л., Болгов Н.Н. Готские «федераты» Боспора и готы-федераты Византии на Боспоре // Научные ведомости БелГУ. - Серия: История. Политология. Экономика. Информатика. - 2010. - 1(72). - Вып. 13. - С. 19-26.

18. Хьюджес Й. Стилихон. Вандал, который спас Рим. - М.: Изд-во «Клио», 2017. - 352 с.

19. Ярцев С.В., Зубарев В.Г., Бутовский А.Ю. Греко-варварский Крым в период поздней античности (III-IV вВ. н.э.: от морских походов до битвы при Адрианополе). - Тула: Изд-во ТГПУ им. Л.Н.Толстого, 2015. - 544 с.

20. Barbero A. Barbari. Immigrati, profughi, deportati nell'impero romano. - Roma, 2008. - 337 p.

21. Demandt A. Magister militum // Paulys Realencyclopädie der classischen Altertumswissenschaft (RE). Supplementband XII. - Stuttgart, 1970. - S. 553-790.

22. Halsall G. Barbarian Migrations and the Roman West, 376-568. - Cambridge: Cambridge University Press, 2007. - 591 p.

23. Heather P.J. Goths and Romans, 332-489. - 0xford: Clarendon Press, 1991. - 378 p.

24. Heather P.J. The Fall of the Roman Empire: A New History. - L.: Pan Macmillan, 2005. - 592 p.

25. O'Flynn J. Generalissimos of the Western Roman Empire. - Edmonton: The University of Alberta Press, 1983. - $250 \mathrm{p}$.

26. Pavan M. La battaglia di Adrianopoli (378) e il probleraa gotico nell'impero romano // Studi romice. - 1978. - V.27. - P.153-165.

27. Piganiol A. L'Empire Chretien (325-395). - P.: Presses universitaires de France, 1972. - 501 p.

28. Rémondon R. La Crise de L'Empire Romain de Marc-Aurèle À Anastase /'Nouvelle Clio': L'Histoire et ses problèmes, XI. - Paris: Presses Universitaires de France, 1964. $-363 \mathrm{p}$.

29. Southern R., Dixon K.R. The Late Roman Army. - L.; New Haven: Taylor \&Francis, 1996. - 240 p.

(с Ярцев Сергей Владимирович (s-yartsev@yandex.ru), Рябцева Марина Леонидовна (ryabtseva@bsu.edu.ru)

Журнал «Современная наука: актуальные проблемы теории и практики» 